\title{
South African government palliative funds for agriculture amid Covid-19: Challenges of implementation and suggestions for improvements
}

Popoola, O.O. ${ }^{1}$ and Yusuf, S.F.G. ${ }^{2}$

Correspondence author: O.O. Popoola. Email: OPopoola@ufh.ac.za

\begin{abstract}
The novel Corona virus pandemic has been extremely overwhelming at all levels causing massive economic setbacks for many countries including South Africa. The country witnessed an unprecedented scaling-down of its national economic activities, which called for an emergency response from the government. Several Covid-19 relief schemes were instituted by the government to ensure that farms of all sizes would survive. A support fund of R1.2 billion was allocated to the agriculture and food sector through the Department of Agriculture, Land Reform and Rural Development (DALRRD). The fund was primarily meant to assist financially distressed small-scale farmers to ensure continued production and food security for the country. This study collated the conditions for financial Covid-19 stimulus support required from smallholders and analysed several factors that prevented some members of this vulnerable group from benefitting from the relief funds. These factors include complexities associated with satisfactorily categorizing smallholder producers, productivity, marketing and policy challenges, glitches in formalising smallholder producer operations, the farm-business record keeping pitfall, and the exclusion of subsistent producers. The paper suggests some possible corrective measures that could allow for more inclusive support to these categories of farmers; some of which includes a simple but robust financial traceability system for the farmers, and a need to continue to push for the completion of national registration process of smallholder producers.
\end{abstract}

Keywords: Intervention fund, smallholder, exclusion, registration, recordkeeping.

\section{INTRODUCTION}

The first confirmed case of Covid-19 in South Africa was announced on 5 March 2020 (Sekyere et al., 2020). The global pandemic has been extremely overwhelming at all levels. The Programme of Land and Agrarian Studies (2020) and the United Nations (2020) predicted loss of income, increased poverty and inequality and widespread hunger. This called for an emergency response from the South African Government, which was announced by President Ramaphosa on 13 May 2020.

Without these interventions, lives and livelihoods could be jeopardized (UN, 2020) and governments across the world were encouraged to support firms forced into lockdown (International Labour Organization [ILO], 2020). In the African Union [AU] (2020) report on the impact of Covid-19 on the African economy, the creation of emergency funding to support individuals and businesses was emphasized as a critical response measure to mitigate the

\footnotetext{
${ }^{1}$ Research Fellow, Department of Agricultural Economics and Extension, University of Fort Hare, Alice, South Africa, Email Address: sopeinoluwabunmi@gmail.com or 201514620@ufh.ac.za,_ORCiD: 0000-0002-85145713

${ }^{2}$ Senior Lecturer, Department of Agricultural Economics and Extension, University of Fort Hare, Alice, South Africa, Email Address: fyusuf@ufh.ac.za or gbolahan4la@yahoo.com,ORCiD: 0000-0002-4156-1221
} 
massive impact of the pandemic. A joint report by the UN-HABITAT, The United Nations Capital Development Fund [UNCDF], United Cities and Local Governments of Africa [UCLG-A Africa], and United Nations Economic Commission for Africa [UNECA] (2020), also stressed the support of local economies as significant to cushioning the effects of Covid19 on national economies. Many governments gave heed (ILO, 2020; UN-Habitat, 2020). Macroeconomic responses that include "direct income-support, tax breaks, extension of [credit] guarantees, [and] deferred interest payments on debt" were widely implemented (AU, 2020:10).

South Africa was on its way to an economic recession before lockdown (Sekyere et al., 2020). This, however, did not deter the government from implementing various Covid-19 response policy measures to assist its citizens Covid-19 relief schemes like the unemployment insurance fund, loan guarantee scheme, social grants, special COVID-19 grants, tax relief and interventions, the solidarity fund and multiple support schemes for small and medium scaled enterprises [SMEs]. The Agriculture and Food sector was granted ZAR 1.2 billion in care of the Department of Agriculture, Land Reform and Rural Development [DALRRD] (Dlothi \& du Plessis, 2020). The Department's Covid-19 Agricultural Disaster Fund was announced by the serving Minister of Agriculture, Land Reform and Rural Development, Ms. Thoko Didiza. The ZAR 1.2 billion fund was primarily meant to assist "financially distressed small-scale farmers" (DALRRD, 2020a: 1) to ensure continued production and food security for the country.

This is an applaudable effort considering that small-scaled agricultural production especially in rural areas lack critical support mechanisms enjoyed by the more technologically advanced commercialized production division. Smallholders are vulnerable to emergencies and financial shocks because they have limited capacities and means. The Department released a communique clearly stating the requirements smallholder farmers must meet to qualify them to access the support fund which some smallholders found difficult to adhere to which excluded them from potential support and left them financial vulnerable in its wake.

The objective of this paper is to collate the conditions for financial COVID-19 support required from smallholders and to analyse the factors that prevented some members of this vulnerable group from benefitting from relief funds. The paper ends with possible corrective measures that could allow for more inclusive support to the sector. This analysis is important because it contributes to the extension profession's ability to respond to any future environmental or public health disaster.

\section{CONDITIONS OF THE COVID-19 AGRICULTURAL DISASTER FUND}

Media statements released by DALRRD (2020b) on the implementation of the Covid-19 Agricultural Disaster Fund stressed that the ZAR 1.2 billion fund was primarily meant to support the completion of the current production cycle to sustain food production during and post Covid-19 pandemic. smallholder and communal farmers who are South African citizens were targeted. ZAR 400 million from the total budget was directed to farmers already in the Proactive Land Acquisition Strategy (PLAS) programme while the rest were allocated to farmers actively producing the under listed commodities DALRRD (2020c). 
Different cost items were covered for each of the four commodity groups:

i. Poultry: Day-old chicks, point of lay chickens, feed, medication and sawdust.

ii. Vegetables: Seedlings, fertilisers, pesticides, herbicides and soil correction.

iii. Fruits: Final spraying programmes for fruits that are ready for harvest.

iv. Other livestock: Feed and medication.

Individual grants were limited to ZAR 50,000 and the scheme ran from 8-22 April 2020. The specific conditions for eligibility are listed in Box 1.

\section{BOX 1: Selection Criteria for Covid-19 Intervention Fund.}

1. Smallholder farmers/producers must have a minimum turnover of R20 000 per annum but not exceeding R1 million. (produce financial records or evidence if financial statement cannot be produced during this lockdown period )

2. South African Certified ID copy; not older than 3 months

3. Valid confirmation of land tenure/ownership (title deeds, Tribal Resolution, Permission to Occupy, minimum 5 years lease agreement)

4. Already farming for more than one year

5. Application form completed

6. Farming operation able to create permanent and/or seasonal jobs

7. In cases where the Environmental Impact Assessment (EIA) Certificate is necessary for the operations, evidence of such to be provided.

8. Proof of access to water for irrigation in case of fruits, vegetables and winter crops (i.e. water license/rights or proof that it had been applied for, borehole or other sources).

Source: DALRRD (2020e: $2-3$; 2020a)

TABLE 1: Composition of successful relief applications by province

\begin{tabular}{|l|c|}
\hline Provinces & Number of approved beneficiaries \\
\hline Eastern Cape & 1551 \\
\hline Free State & 393 \\
\hline Gauteng & 981 \\
\hline KwaZulu-Natal & 2791 \\
\hline Limpopo & 1940 \\
\hline Mpumalanga & 810 \\
\hline North West & 2906 \\
\hline Northern Cape & 1413 \\
\hline Western Cape & 1554 \\
\hline Total & $\mathbf{1 4 , 3 3 9}$ \\
\hline
\end{tabular}

Source: DALRRD, $2020 \mathrm{f}$

The Minister announced the outcome of the relief fund process on the $17^{\text {th }}$ of May, 2020 (DALRRD, 2020b). Around 55155 applications were received by the Department with the Eastern Cape Province and livestock producers having the highest number of applications. The final lists of COVID-19 disaster fund beneficiaries submitted to the Chairperson of Portfolio Committee showed that only 14, 339 applications (25.99\%) were successful at the national level with KwaZulu-Natal and Free State provinces having the highest and lowest approval 
rates of 2791 and 393 respectively (Table 1). This approval ratings calls for a great concern as the number of unsuccessful applications far outweighs the applications that scaled through the vetting processes; indicating that majority $(74 \%)$ of the farmers failed to meet the laid down selection criteria.

\section{WHO ARE THE SMALLHOLDER FARMERS?}

The use of the term 'smallholder' in the context of South Africa has been questioned by several scholars like Aliber, Hart and O'Donovan (2009), Greenberg (2013) amongst others (Chikazunga \& Paradza, 2013). The complex use of the term and many others like 'subsistence, resource poor, peasant, small-scale, family, emerging' (Department of Agriculture, Forestry \& Fisheries [DAFF], 2012; Pienaar \& Traub, 2015), for the less developed agricultural sector seems to classify the farmers who fall within this class as a homogenous group.

The term 'smallholder' is problematic, however, because it tends to obscure inequalities and class based differences within the large population of households engaged in agricultural production on a relatively small scale. Much usage suggests that smallholders form a relatively homogeneous group, and fails to distinguish between those producers for whom farming constitutes only a partial contribution to their social reproduction, those for whom farming meets most of their social reproduction requirements, and those for whom farming produces a significant surplus, allowing profits to be reinvested and, for some, capital accumulation in agriculture to begin (Cousins, 2010:2).

Agreed that there are many synonymous elements pooling these farmers under one umbrella; elements like the level of access to capital assets, infrastructure, advanced production technologies and inputs, markets, market orientation, and production lands amongst many others (DAFF, 2012; Kamara et al., 2019), allow for clear-cut inequalities to exist within this group. Pienaar and Traub's (2015) study further re-emphasized the extensive diversification existing within the smallholder sector. Differences that exist in smalholders' characteristics, capital assets, farm size, and proportion of farm produce sold, household spending, use of external inputs and hired labour, and off-farm employment (DAFF, 2012), as farmers employ different approaches to buffer their livelihood resilience. These differences tend to play a huge role in determining which of the farmers in the sector are comparatively advantaged over others when it comes to accessing social protection interventions like the Covid-19 agricultural disaster fund.

In Chikazunga and Paradza's (2013:4) view, the smallholder farm sector is a range of farm categories from subsistence to commercial meaning that smallholder farmers could be "resource-rich, resource-poor or somewhere in between, and could be involved in commercial production, semi-subsistence production or somewhere in between". DAFF in its 2018 document on the 'National Policy on Comprehensive Producer Development Support', categorized South African smallholder producer sector as:

A venture undertaken by an individual or business entity for the purpose of household consumption and deriving a source of income from agriculture, forestry and fisheries activities along the value chain. These are usually the new entrants with an annual turnover ranging from $R 50000$ - R5 million per annum (DAFF, 2018:12). 
The Department's 2013 Strategic Plan for smallholder support identified three types (Box 2).

\section{BOX 2: Smallholder Producer Typologies.}

SP1 ('Smallholder producer type 1'): Smallholders for whom production is a part-time activity that forms a relatively small part of a multiple-livelihood strategy.

SP2 ("Smallholder producer type 2"): Smallholders who are more or less in the middle of the spectrum, they rely largely on their agricultural enterprises to support themselves and are not living in poverty, but need further assistance both to expand production, join in the value addition and find markets.

SP3 ("Smallholder producer type 3"): Smallholders who operate according to commercial norms but who have not reached the threshold at which they are obliged to register for VAT or personal income taxes.

\section{Source: DAFF (2013:6)}

DALRRD's requirement for smallholder and communal producers to have a farm business turnover of between R20000 - 1000 000, directed the department's aid to market-based activities and excluded subsistence production altogether. It also perhaps inadvertently excluded those smallholders whose market activities are still modest. It is noted though that a minimum turnover of R50 000 applied before (DAFF, 2018).

We argued that many smallholder producers may have failed to meet this requirement, with reasons that smallholder producers face multiple challenges during production through to the marketing of produce. Some of these challenges would again be re-emphasized in the subsequent sections of this paper.

\section{PRODUCTIVITY, MARKETING AND POLICY CHALLENGES}

Agricultural smallholder producers are significant drivers of many developing national economies (IDH, the Sustainable Trade Initiative, 2020). Despite this, their productivity level remains relatively low (Kamara et al., 2019), and only a few, will be able to successfully transition into a profitable agricultural production business as they continually face competitive pressure from economic globalism and integration into common trade and industrial areas (Food and Agriculture Organization [FAO], 2012; Fan et al., 2013). In South Africa, Myeni et al. (2019) points to several literature which reiterates the low productivity of its crop smallholder producers despite many intervention efforts of many public and private stakeholders. The Eastern Cape Province for instance, is extensively subsistent production based with significantly low productivity and income (Mujuru \& Obi, 2020). There are myriads of factors limiting production efficiencies and earnings of smallholder producers (Khanal et al., 2018). OXFAM's 2018 discussion paper, argued that central to smallholder productivity and income challenge is the existing crucial imbalance between having to shoulder agricultural production associated risks and the power to shape their participation in markets. Some of the pronounced productivity challenges as identified in literature (DAFF, 2012; Aliber \& Hall, 2012; Fan et al., 2013; Mpandeli \& Maponya, 2014; Sikhweniab \& Hassan, 2014; Khapayi \& Celliers, 2016; OXFAM, 2018; Myeni et al., 2019; Kamara et al, 2019; IDH, , the Sustainable Trade Initiative, 2020) include, lack of capital assets; narrowed down financial choices; production input risks in relation to supply, costs, capacity and quality; climate change threats; land issues related to tenure, dimensions and quality; dearth of production information; lack of 
robust institutional and infrastructural support mechanisms; limited access to credit facilities; inadequate production knowledge and competencies; increased livestock predation, theft and diseases and, price shocks associated with low and unstable produce prices.

An all-inclusive, reliable and sustainable market access is essential to smallholder farmer's production investment capacity (OXFAM, 2018). Accessibility to efficient and well functional markets allows for smallholder farmers market participation which significantly enhances their farm earnings (Sikhweniab \& Hassan, 2014). In South Africa, there has been concerted efforts to strengthen smallholder farmer's linkage to its value chains and improve their participation in the modern market channels (Aliber, 2013; Chikazunga, 2013). Despite this, many smallholder producers remain inactive in these value chains because of high entry barriers and limited incentives (OXFAM, 2018). Chikazunga's (2013:16) viewpoint is that, the South African modern-day markets comprising of supermarkets, traders and processors have taken up dominance and are the major determinants of the choice of food producers, the expected quality and quantity of produce and price variations; and are being further strengthened by the "introduction of private procurement standards for coordinating food quality and safety requirements between consumers and producers". This shift has led to increased risks of exclusion of many smallholder producers from food markets. According to Louw (2013:27) "procuring from smallholder farmers has always been a challenge for large businesses in terms of organizing supply, quantity, consistency, quality, safety and traceability, because to ensure all these involves high transaction costs". At the supply chain level, the inequalities in risk and power are exhibited in the caged relationships between a sizeable and fragmented group of farmers and a centralized group of buyers in several commodity sectors (OXFAM, 2018). Other smallholder farmer market challenges include inadequate agro-market services, unavailable and unpredictable input and output commodity markets, shortage of assets, dearth of market information, poor road infrastructure, unreliable distribution network and, unequal bargaining power (DAFF, 2012; Kibirige, 2016; IDH, the Sustainable Trade Initiative, 2020). As such, smallholder producers find it difficult to compete with large scaled commercial producers who control close to $85 \%$ share of the country's agricultural market (Kibirige, 2016).

The policy domain plays a critical role in putting into shape good investments and market structures for smallholder producers (Vorley, Cotula \& Chan, 2012). In South Africa, there are existing policies like the land reform and preferential procurement policy frameworks enacted by the government to bridge the gaps between the smallholder and large commercial agricultural sectors; despite the many policy efforts, smallholder producers are nowhere close to being at par with their large-scale commercial counterparts (Louw, 2013).

While the focus of agricultural production and marketing programmes in South Africa has shifted to smallholder production, legislative and policy measures for creating an enabling environment for smallholders to establish sustainable and competitive production and marketing systems have not been provided (Hendriks, 2014:12).

Smallholder farmers are crucial in benchmarking local economic development, food security and as incubators for cottage industrial development. An innovative way of classifying the sector such that more producers can benefit from government palliative support will go a long way towards helping them achieve their crucial roles of economic development. The innovative and creative classification can only come from the agricultural extension service being the major role player in the smallholder farming activities. By conducting productivity assessment 
of the smallholder farmers, the agricultural extension services could see many of this category of farmers benefiting maximally from any of the government stimulus package like covid-19 agricultural disaster fund. Fan et al (2013:16) succinctly elaborated that "while some smallholder farmers have the potential to undertake profitable commercial activities in the agricultural sector, other farmers should be supported in exiting agriculture and seeking nonfarm employment opportunities". This is to give room to efficient smallholder producers to expand their farm operations. This is where the role of South Africa's extension institution becomes germane in conducting productivity assessment program for smallholder farmers in its provinces to be able to competently re-classify smallholder farmers and innovate diverse extension support schemes for each distinct smallholder farmer group.

\section{FORMALISING SMALLHOLDER PRODUCER OPERATIONS}

Another primary criterion for qualifying for the Agricultural Disaster Fund was that the smallholder and communal producers had to be formally registered on South Africa's official farmer register, one or more commodity data base or on their provincial data base. When the application process closed in late April, the Minister made the following statement:

It saddens me that during this process many of them fell by the wayside because they could not provide proof that they are farmers or farming. The registration of farmers on the Producer Farmer Register will enable government to locate farmers so that targeted support can be provided (DALRRD, 2020b:2).

A primary reason why many smallholder producers particularly the black farmers, were excluded from receiving government support seems to be that the country's agricultural departments are unaware of their existence (Aliber \& Hall, 2012). This criticism resulted in setting up the national farmer database, which was first tested as a pilot project by DAFF in 2008 (Aliber \& Hall, 2012). The main purpose for the farmer register is to institute an up-todate statistics for all South African producers such that DAFF and other related institutions can have access to accurate statistics of existing agricultural producers in the region (DAFF, 2009); asides, it gives a leeway to delivering appropriate government and private support services to the farmers. In 2018, DAFF announced its intention to embark on a 'producer/farmer register campaign' in conjunction with Statistics SA. The campaign was anticipated to run from 2018 to 2021. However, the outbreak of the covid-19 pandemic disrupted the smooth running of the Producer/Farmer registration campaign. It is unfortunate that the Covid-19 pandemic had to come into global existence and far more unfortunate that it had to show up prior to the completion of the producer/farmer register campaign. Perhaps, several smallholder producers who could have participated in the registration campaign may not have been excluded from benefiting from the disaster fund if they had been formally registered. The delayed registration process particularly for smallholder farmers was in part due to the phased approach of the registration process as implemented by DAFF; according to Kuschke and Cassim (2019:19), "the census would be conducted in two parts, focusing on commercial farmers in 2019 and smallholder farmers in 2020". Lesson from this approach is that such campaign should have run in parallel, that is, commercial and smallholder farmers at the same time. However, one may not have reasons to why it was fixed at different time, which could be logistic, or other compelling challenges. The authors therefore suggest that by the end of the campaign, if it is ever completed, analysis on the scope of the campaign coverage in all provinces should be carried out to assess the level of success. In addition, successful registration of smallholder farmers could be instrumental in having a better insight into the productivity diversities in the 
smallholder sector and in calling for a more reoriented classification system and policy approach to sustain the sector.

\section{THE FARM-BUSINESS RECORD KEEPING PITFALL}

The other critical issue raised in the DALRRD (2020b) media statement is the problem smallholder producers have in formalising their operations particularly in record-keeping. The Department noted major issues with the lack of proper documentation or filing of documents by a handful of farmers who were at the least, able to provide some form of documentation. There are yet, many others who could not meet up with the criteria of providing financial records or any evidence showing that their farm business turnover was between R20,000 and R1 million. For instance, many smallholder farmers may not be able to provide the 6 months of bank statement or evidence of recorded farm annual sales requested for by DALRRD in the Covid-19 disaster fund application form. This is a very onerous requirement for people who mainly engage in cash transactions when they buy inputs or sell outputs and often do not have bank accounts.

Several studies have reiterated the significance of keeping basic farm records (Drafor, 2011; Adedapo \& Adekunmi, 2019). Many farmers probably do not attach too much importance to keeping accurate records as they mostly rely on their memories, intuitions and estimations when making critical operational decisions (Dudafai, 2013; Obinaju \& Ekpo, 2017; Sharma \& Dubey, 2019). Reasons could be that they lack the basic skills in record keeping or are perhaps, ignorant as to how it can be beneficial to their business (FAO, 2011). Many farmers do not recognize the significance of recording and traceability systems and how the lack of it, could affect their efficiency, business development, and integration with downstream partners (Bachev \& Tanic, 2011). This is often relatable especially to smallholder farmers who often do not keep adequate farm records like their large-scale commercial counterparts (Drafor, 2011; International Finance Corporation [IFC], 2013). According to Obinaju and Ekpo (2017:164) record keeping "is not an end itself, but a means to an end, it therefore does not make a business profitable but can be used as a performance indicator tool". Therefore, keeping business records on assets, production, labour, trainings, cash flow, profit and loss, and consumption (FAO, 2011; Farming as a Business, [FAAB], 2018; Simpa 2019), could provide farmers with the comparative edge they require in accessing important financial aid schemes alongside other additional benefits. In Simpa's (2019) perspective, government institutions require farm records in implementing developmental schemes and, instituting production controls, policies, research development and trainings. It is, therefore, critical to continually create farm recordkeeping awareness amongst smallholder farmers.

Many smallholders have little formal education, which limits their ability to keep adequate written records or educate themselves about improved agricultural practices. They may have only a vague idea of basic metrics, such as farm size, crop yield, and real costs, on their own farms (IFC, 2013:3).

In the short-term, there is a critical need for extension field to identify specific farm-business record keeping training needs of the farmers and implement practical ways of enhancing their recordkeeping knowledge and skills. In the long-term, Extension service could institute a productivity and financial traceability system for South African smallholder farmers through the planning and implementation of initiatives like the 'smallholder assisted farm recordkeeping program' with the main aim of providing smallholder farmers (particularly those with low literacy and numerical capacity) with the necessary aid in facilitating their farm 
recording activities. In time, the possibility of a more advanced digital procedure of recordkeeping may be infused so long as such technologies are simple, user friendly and considered adaptable.

\section{THE EXCLUSION OF SUBSISTENT PRODUCERS}

Subsistence farmers were simply not considered for COVID 19 relief. Understandably so, almost certainly because they ventured into farming as a supplementary livelihood activity to contribute to their own household food security. For these farmers, the business side to food production is far-fetched; but not necessarily due to a lack of interest in making a profitable business out of it. Evidently this group of producers' most likely fall into DAFF's (2013) "smallholder producer type 1" (SP1) classification. Like their market-oriented smallholder counterparts, they are faced with myriads of similar production, marketing, and policy challenges in addition to being resource-poor. In DAFF's (2013:6) estimate, majority of these farmers fall within the purview of the more than 50\% smallholder South African households living in poverty; "this category of smallholders is worthy of focused support".

Statistics South Africa (2019) reported that data collected from the General Household Survey 2017 showed that provinces like Limpopo, Eastern Cape and KwaZulu-Natal which are largely rural and with high poverty level, had the highest population of agricultural households. This further validates studies which constantly reiterate that poverty and food insecurity is rife among rural farming households. For instance, Omotesho Muhammad-Lawal and Ismaila (2014) stressed that majority of the starving population reside in rural communities and are mostly farming household members. One would think that households involved in agricultural production should ordinarily be food secure. It is expected that they should be (Alemu, 2015); but evidence from countless literature suggests otherwise. According to Sibhatu and Qaim (2017), it is ironic that Sub-Saharan rural smallholder farming households have been found to be extremely affected by food insecurity despite their crop and livestock production activities. Evidence suggests that food security conditions of farming households is worrisome as a significant number of these households have been found to be either food insecure or at the brink of food security line (Ahmed et al., 2017). They are also susceptible to high food prices and irregular food supply which are more often, of poor quality (Olajide, 2014). That South Africa is food secure at the national level does not erase the fact that it is still struggling to become food secure at its household level especially in its rural regions (SSA, 2019). The Covid-19 pandemic has only further exacerbated these conditions.

Households in the lowest income categories tend to be significantly more affected by economic shocks compared to households in higher income categories, hence the significant increase in food poverty levels during the economic crisis (SSA, 2019:4).

One would therefore expect that the social protection net being cast at agricultural producers in emergency situations like the Covid-19 pandemic should also be fairly extended towards farming households producing at a subsistent level. This is critical; as "hunger may occur when households are unable to grow or purchase adequate food coupled with the absent of social welfare networks" (Ogundiran et al., 2014:130). According to Dube and Selvaggio (2013), DAFF had in the past supported household level food production and had implemented schemes like the Household Food Production, Food Security and Starter Packs Project, Special Programme for Food Security Projects [SPFS] and the National Food Emergency Scheme [NFES] which were primarily directed at promoting agricultural production at the household level. The authors however, observed that the revised DAFF Strategic Plan (2013/14-2017/18) 
had obscured household food producers and focused more on supporting market-oriented smallholder producers instead, with the aim of increasing their sales and profitability. In other words, household food producers had been sidelined. This is strikingly similar as yet again, subsistent farmers seemed to have been shelved and the focus, primarily shifted towards providing emergency support funding for smallholder producers with 'benefits. Household food production is significant and can potentially contribute to household and communal food security; it however requires extensive support (Misselhorn \& Hendriks, 2017). To reiterate, the choice remains whether to provide them with the needed support to "continue doing what they are already doing" but at a much larger scale such that they can sustainably meet their household food requirements (Aliber \& Hall, 2012:560).

\section{CONCLUSION AND RECOMMENDATIONS}

The emergency response of the South African Government to assist its citizens by implementing several Covid-19 intervention schemes is indeed laudable. The ZAR 1.2 billion provided by the government to support its smallholder producers and communal farmers was a much-needed intervention for this group of farmers. However, the conditions set for accessing the financial incentive, and several other factors had prevented many of the smallholder farmers from becoming beneficiaries of the support fund. Some of these factors including production challenges, marketing obstacle, policy barriers, lack of proper registration of producers, and financial recordkeeping drawbacks had played some form of roles in the exclusion process of accessing the relief fund.

The study therefore recommends continuous farmers' registration program to accommodate new entrants that will ensure their immediate capturing in the farmers' database to allow them gain access to already existing and/or new government support schemes. The agricultural extension services should also intensify the awareness campaign on farm record keeping. In this wise, the study recommends a model (table 2) that could enhance financial traceability of farmers through record keeping. 
TABLE 2: A smallholder producer assisted farm recordkeeping model.

\begin{tabular}{|c|c|}
\hline & Prospective roles \\
\hline $\begin{array}{l}\text { South Africa's } \text { Extension } \\
\text { Service }\end{array}$ & $\begin{array}{l}\text { 1. Institute a productivity and financial traceability system for South African smallholder farmers through the planning and } \\
\text { implementation of initiatives like the 'smallholder assisted farm recordkeeping program' with the main aim of providing } \\
\text { smallholder farmers (particularly those with low literacy and numerical aptitude) with the necessary aid in facilitating } \\
\text { their farm recordkeeping activities. } \\
\text { 2. Implement a pilot project in one or more districts in selected provinces for one production cycle. } \\
\text { 3. Facilitate the recruitment of literate unemployed youths living in communal areas where smallholder producers are } \\
\text { situated. Successful applicants can be drafted as 'Smallholder Farm Operation Documentation Facilitators [SFODFs]. } \\
\text { 4. Facilitate the mass production of farm ledgers that could be distributed to the smallholder producers at a discounted rate. } \\
\text { 5. Implement a functional feedback system to allow for proper monitoring and evaluation of the program. }\end{array}$ \\
\hline Extension Field Officers & $\begin{array}{l}\text { 1. Identify specific farm-business record keeping training needs of the farmers and implement practical ways of enhancing } \\
\text { their recordkeeping knowledge and skills. } \\
\text { 2. Train SFODFs in all aspects of farm production record keeping. } \\
\text { 3. Play a mediatory role between the smallholder producers and SFODFs } \\
\text { 4. Train smallholder producers on using a manual filing system and the use of mobile phone technology in capturing their } \\
\text { weekly or monthly farm activities either through pictures or voice recording. } \\
\text { 5. Monitor the documentation processes for their respective zones. }\end{array}$ \\
\hline $\begin{array}{l}\text { Smallholder Farm Operation } \\
\text { Documentation Facilitators } \\
\text { [SFODFs]. }\end{array}$ & $\begin{array}{l}\text { 1. Act in the capacity of 'thrift collectors.' } \\
\text { 2. Visit smallholder producers in their respective zones to assist them in collating production data on a weekly or monthly } \\
\text { basis. } \\
\text { 3. Provide regular feedback to their supervising officers (extension field agents). }\end{array}$ \\
\hline Smallholder Producers & $\begin{array}{l}\text { 1. Make the documentation process easy for SFODFs by learning to using a manual filing system and their mobile phones } \\
\text { to capture their weekly or monthly farm activities either through pictures or voice recording. }\end{array}$ \\
\hline
\end{tabular}




\section{REFERENCES}

ADEDAPO, A.O. \& ADEKUNMI, A.O., 2019. Factors influencing the choice of record keeping among poultry farmers in Ekiti state, Nigeria. IJA 31(1):1-15.

AFRICAN UNION (AU), 2020. Impact of the Coronavirus (Covid 19) on the African economy. Available from:https://www.tralac.org/documents/resources/covid19/3218-impact-of-the-coronavirus-covid-19-on-the-african-economy-africanunion-report-april-2020/file.html.

AHMED, U.I., YING, L., BASHIR, M.K., ABID, M. \& ZULFIQAR, F., 2017. Status and determinants of small farming households' food security and role of market access in enhancing food security in rural Pakistan. PloS one, 12(10), p.e0185466.

ALEMU, Z.G., 2015. Developing a food (in) security map for South Africa. African Development Bank Group. Working Paper Series N 220 African Development Bank, Tunis, Tunisia. Available from: https://www.afdb.org/fileadmin/uploads/afdb/Documents/Publications/WPS_ No_220_Developing_a_food_in_security_map_for_South_Africa_BB.pdf.

ALIBER, M., HART, T. \& O'DONOVAN, M., 2009. Review of rural development: 15 year review of economic and social sector programmes. HSRC publication.

ALIBER, M. \& HALL, R., 2012. Support for smallholder farmers in South Africa: Challenges of scale and strategy. Dev. South. Afr., 29(4):548-562.

ALIBER, M., 2013. Conceptualising approaches to smallholders and markets. In S. Greenberg, (ed.), Smallholders and agro-food value chains in South Africa: Emerging practices, emerging challenges. Bellville: Institute for Poverty, Land and Agrarian Studies, School of Government, University of the Western Cape. Available from: http://repository.uwc.ac.za/xmlui/handle/10566/4339.

BACHEV, H. \& TANIC, S., 2011. Issues and challenges for farm and enterprise diversification and integration of small scale farmers into value chains in EECA. Available from: https://www.researchgate.net/profile/Hrabrin_Bachev_Hrabrin_Bashev_Chrab rin_Bashev/publication/256018755_Farm_and_Enterprise_Diversification_in_ East_Europe_and_Central_Asia/links/5e8cc535a6fdcca789fdd4fd/Farm-andEnterprise-Diversification-in-East-Europe-and-Central-Asia.pdf.

CHIKAZUNGA, D., 2013. Determinants of smallholder farmers' participation in modern food markets: The case of tomato supply chains in Limpopo. In S. Greenberg, ed., Smallholders and agro-food value chains in South Africa: Emerging practices, emerging challenges. Bellville: Institute for Poverty, Land and Agrarian Studies, School of Government, University of the Western Cape. Available from: http://repository.uwc.ac.za/xmlui/handle/10566/4339. 
CHIKAZUNGA, D. \& PARADZA, G., 2013. Smallholder farming: A panacea for employment creation and enterprise development in South Africa? Lessons from the Pro-Poor Value Chain Governance Project in Limpopo Province. Working Paper 27. PLAAS, UWC: Bellville.

COUSINS, B., 2010. What is a 'smallholder'? Class-analytic perspectives on smallscale farming and agrarian reform in South Africa. Working Paper \#16. Available from: https://media.africaportal.org/documents/WP16.pdf.

DEPARTMENT OF AGRICULTURE, FORESTRY AND FISHERIES (DAFF), 2009. Farmer register pilot study - statistical report - 2009. Available from: https://www.daff.gov.za/docs/statsinfo/FarmRegPilotStudy.pdf.

DEPARTMENT OF AGRICULTURE, FORESTRY AND FISHERIES (DAFF),, 2012. A framework for the development of smallholder farmers through cooperative development. Available from: http://www.nda.agric.za/doaDev/sideMenu/cooperativeandenterprisedevelopm ent/docs/framework-\%20of\%20small\%20farmers\%20(2).pdf.

DEPARTMENT OF AGRICULTURE, FORESTRY AND FISHERIES (DAFF),, 2013. Strategic plan for smallholder support 2011-2015. Pretoria: Republic of South Africa. Available from: http://www.nda.agric.za/doaDev/sideMenu/SmallHolder/docs/Strategic\%20P1 an\%20for\%20Smallholder\%20Support.pdf.

DEPARTMENT OF AGRICULTURE, FORESTRY AND FISHERIES (DAFF),, 2018. National policy on comprehensive producer development support: Draft 5 ver. $3 . \quad 30$ May 2018. Available from: https://www.daff.gov.za/docs/media/Draft\%205\%20ver\%203\%20Policy\%20o n\%20CPDS_30May2018_accepted\%20change.pdf.

DEPARTMENT OF AGRICULTURE, LAND REFORM AND RURAL DEVELOPMENT (DALRRD)., 2020a. Media statement on the interventions to assist the agricultural sector during covid-19. Available from: https://www.daff.gov.za/docs/media/KZN\%20Applications\%20_\%20Intervent ions $\% 20$ to $\% 20$ assist $\% 20$ the $\% 20$ Agricultural $\% 20$ Sector $\% 20$ during $\% 20 \mathrm{COVI}$ D-19.pdf.

DEPARTMENT OF AGRICULTURE, LAND REFORM AND RURAL DEVELOPMENT (DALRRD),, 2020b. Media statement 17 May 2020: Minister Didiza announces the outcome of the covid-19 agricultural disaster fund application process. Available from: https://www.daff.gov.za/docs/media/Statement\%20on\%20the\%20outcome\%2 0of $\% 20$ the $\% 20$ agriculture $\% 20$ distaster $\% 20$ fund $\% 20$ application $\% 20$ process.p df.

DEPARTMENT OF AGRICULTURE, LAND REFORM AND RURAL DEVELOPMENT (DALRRD)., 2020c. Media statement 29 April 2020. 
Minister Didiza announces the way forward upon closure of covid-19 intervention application process. Available from: https://www.daff.gov.za/daffweb3/Home/COVID-19-updates.

DEPARTMENT OF AGRICULTURE, LAND REFORM AND RURAL DEVELOPMENT (DALRRD)., 2020d. Request for expression of interest (Rei) to supply farmers with production inputs: Covid-19 Disaster Intervention Programme. Available from: https://www.daff.gov.za/docs/media/Request\%20Expression\%20of\%20Interes t\%20Supply\%20for\%20Farmers\%2018042020.pdf.

DEPARTMENT OF AGRICULTURE, LAND REFORM AND RURAL DEVELOPMENT (DALRRD),, 2020e. Call for applications: Covid-19 agricultural disaster support fund for smallholder and communal farmers. Available from: https://www.daff.gov.za/daffweb3/Home/COVID-19-updates.

DEPARTMENT OF AGRICULTURE, LAND REFORM AND RURAL DEVELOPMENT (DALRRD)., 2020f. List of COVID-19 disaster fund beneficiaries to Chairperson of Portfolio Committee. Available from: / https://www.dalrrd.gov.za/Home/COVID-19-updates/COVID-19-DISASTERFUND-BENEFICIARIES.

DLOTHI, K. \& DU PLESSIS, Q., 2020. Relief packages and support to South Africans amid the COVID-19 pandemic. A White \& Case Report. Available from: https://www.whitecase.com/sites/default/files/2020-04/relief-packagessupport-south-africans-amid-the-covid-19-pandemic.pdf.

DRAFOR, I., 2011. Rural household capacity building: Innovative approaches to ensure adoption ofrecord keeping by farm households. Int. J. Agric. Manag., 1(1):4-28.

DUBE, S. \& SELVAGGIO, M.P., 2013. Household food production and preservation (home gardens). Case study report diagnostic/implementation evaluation of nutrition interventions for children from conception to age 5. South Africa Department of Performance Monitoring and Evaluation (DPME) Nutrition SLA $12 / 0287$.

DUDAFA, U.J., 2013. Record keeping among small farmers in Nigeria: Problems and prospects. IJSRE PIENAAR, L. \& TRAUB, L., 2015. Understanding the smallholder farmer in South.

PIENAAR, L. \& TRAUB, L., 2015. Africa: Towards a sustainable livelihoods classification. (No. 1008-2016-79955). The 29th International Conference of Agricultural Economists [ICAE], August 9-14, 2015, Milan, Italy.

SEKYERE, E., BOHLER-MULLER, N., HONGORO, C. \& MAKOAE, M., 2020. The impact of Covid-19 in South Africa. Wilson Center, Africa Program Occasional Paper. Available from: https://www.wilsoncenter.org/publication/impactcovid-19-south-africa. 
SHARMA, J.K. \& DUBEY, P.K., 2019. A Need of Farm Records and Accounting in Agriculture Sector. IJISSH 4(5):155-158.

SIBHATU, K.T. \& QAIM, M., 2017. Rural food security, subsistence agriculture, and seasonality. PloS one, 12(10), p.e0186406.

SIKHWENI, N.P. \& HASSAN, R., 2014. Determinants of herd size among small-scale cattle farmers: The case of selected villages at the Mhinga Traditional Authority in Limpopo, South Africa. Agrekon, 53(4):106-122.

SIMPA, O.J., 2019. Farm records, bookkeeping and agricultural data: A case study of small-scale farmers in Nasarawa state, Nigeria. PAT, 15(1):23-32.

STATISTICS SOUTH AFRICA (SSA)., 2019. Towards measuring the extent of food security in South Africa: An examination of hunger and food inadequacy. Report: 03-00-14. Available from: http://www.statssa.gov.za/publications/0300-14/03-00-142017.pdf.

THAMAGA-CHITJA, J.M., \& MOROJELE, P., 2014. The context of smallholder farming in South Africa: Towards a livelihood asset building framework. Journal of Human Ecology, 45(2):147-155.

UN-HABITAT., 2020. Covid-19 in African cities impacts, responses and policies. Available from: https://unhabitat.org/covid-19-in-africa-cities-impactsresponses-and-policies.

UN-HABITAT, THE UNITED NATIONS CAPITAL DEVELOPMENT FUND (UNCDF), UNITED CITIES AND LOCAL GOVERNMENTS OF AFRICA (UCLG-A AFRICA) \& UNITED NATIONS ECONOMIC COMMISSION FOR AFRICA (UNECA)., 2020. New report, COVID-19 in African cities: Impacts, responses and policies, launched by ECA \& partners. Available from: https://www.tralac.org/news/article/14664-new-report-covid-19-in-africancities-impacts-responses-and-policies-launched-by-eca-partners.html.

UNITED NATIONS (UN)., 2020. A UN framework for the immediate socio-economic response to COVID-19. Available from: https://unsdg.un.org/resources/unframework-immediate-socio-economic-response-covid-19.

VORLEY, B., COTULA, L. \& CHAN, M.K., 2012. Tipping the balance: Policies to shape agricultural investments and markets in favour of small-scale farmers. Oxfam Policy and Practice: Private Sector, 9(2):59-146. 